University of Nebraska - Lincoln

DigitalCommons@University of Nebraska - Lincoln

Agronomy \& Horticulture -- Faculty Publications

Agronomy and Horticulture Department

$10-1933$

\title{
Effect of Frequent Clipping on the Development of Roots and Tops of Grasses in Prairie Sod
}

\author{
Harold Biswell \\ University of Nebraska-Lincoln \\ J. E. Weaver \\ University of Nebraska-Lincoln
}

Follow this and additional works at: https://digitalcommons.unl.edu/agronomyfacpub

Part of the Plant Sciences Commons

Biswell, Harold and Weaver, J. E., "Effect of Frequent Clipping on the Development of Roots and Tops of Grasses in Prairie Sod" (1933). Agronomy \& Horticulture -- Faculty Publications. 461.

https://digitalcommons.unl.edu/agronomyfacpub/461

This Article is brought to you for free and open access by the Agronomy and Horticulture Department at DigitalCommons@University of Nebraska - Lincoln. It has been accepted for inclusion in Agronomy \& Horticulture -Faculty Publications by an authorized administrator of DigitalCommons@University of Nebraska - Lincoln. 


\title{
EFFECT OF FREQUENT CLIPPING ON THE DEVELOPMENT OF ROOTS AND TOPS OF GRASSES IN PRAIRIE SOD ${ }^{1}$
}

\author{
Harold H. Biswell and J. F. Weaver
}

\section{University of Nebraska}

A study has been made of the regeneration of bluestem grasses in exclosures in continuously grazed native pastures. The persistence of remnants of the bunches or mats of sod in old pastures for a long period of years is of interest, as is also their gradual but slow rate of recovery under protection when they are greatly weakened. Even in low, fertile, well watered soil, a period of three or four years must elapse before such species as Andropogon furcatus and Sorghastrum nutans produce the usual abundance of flower: stalks and large quantities of viable seed. The first summer only a poor growth of scattered foliage outlines in a fragmentary manner the location of the underground parts that have been thoroughly weakened by continuous depletion of their food supplies. A second growing season shows a marked filling in of the sodded areas or clumps and about half the normal production of foliage. During the third summer the area is further extended and at least a few flower stalks and some seed are usually produced.

During this process of recovery it was repeatedly noticed that these grasses were much more subject to wilting than were similar species in adjacent areas that had not been grazed. The leaves would roll or fold and many of the lower ones dry and lose their green color. The evidence pointed clearly to a meager or inefficient root system.

The quantitative development of roots or their degree of deterioration is difficult to study under field conditions because of the labor involved in separating the living rhizomes and fibrous roots from those that are dead and from partially decomposed fragments of leaves, etc., intermixed with them. Earlier experiments where blocks of sod were transplanted showed that new roots were rapidly developed (Clements and Weaver, '24). Hence it was decided to select representative samples of the several most important native grasses, cut out blocks of soil containing them, and transplant these into large containers filled with soil free from roots and debris. One lot of each was to be clipped at I4-day intervals and the duplicates were to be grown as controls.

Grazing is a more or less destructive process since it periodically removes much of the photosynthetic area of the plants and an abrupt decrease in the photosynthetic activity causes a corresponding decrease in the growth of the

1 The publication of the extra pages and extra illustrations of this article has been made possible by funds other than those of the Ecological Society of America.

Contribution from the Department of Botany, University of Nebraska, No. 8I. 
roots. Continued defoliation will cause destruction of the root system and result in death. Hence, unless reasonable precautions are taken, the effects of grazing are likely to become cumulative and cause serious deterioration of the range.

The effect of the removal of the photosynthetic area upon the growth of the tops has received considerable study. Many data have been obtained from clipping vegetation in the western two-thirds of the United States. They show that the yield and vigor of the vegetation varies inversely with the frequency of clipping.

Crozier ('97) in Michigan, found that frequent mowing of various cultivated grasses reduced the yield to one-fourth normal and that the yields were highest on the plots clipped least frequently.

Sampson ('I4), working in the Wallowa National Forest in Oregon, found that when Festuca viridula, one of the chief forage species, was clipped three times each season during a period of three consecutive years, the vegetative growth decreased in abundance each successive season.

Sarvis ('23), working in the mixed prairie of North Dakota, found that Stipa comata disappeared entirely under frequent harvesting and that various. other grasses showed lowered vitality. The highest yields were obtained from plots clipped at 40-day intervals and the lowest from those clipped every io days.

Sampson and Malmsten ('26), in a study of forage species in Utah, found that the removal of the herbage four or more times in a season resulted in a sharp decline in yield and in a marked shortage of the life of the vegetation. Stipa lettermani and Agropyron violaceum, clipped five times annually for three successive years, yielded in the third year only i2 and 9 per cent respectively, of the amount of herbage that was produced during the first year of clipping. A short-lived perennial, Bromus polyanthus, died under similar treatment.

McCarty ('27), working in Colorado, judged yields on a basis of their calculated values for the second year of treatment, thus attempting to elim. inate seasonal variation from year to year. "Quadrats of Agropyron smithii, harvested four times during one year, yielded 84 per cent of their calculated value during the second year of treatment. Quadrats harvested seven and eight times in one year yielded, respectively, 50 per cent and 40 per cent of their estimated values during the succeeding year."

Graber et al. ('27), in Wisconsin, showed that the productivity of well established bluegrass sod, following two years of frequent cuttings, was reduced to less than one-fourth that of adjacent bluegrass, Poa pratensis, cut but once annually at maturity. Similar results were obtained with red top, Agrostis alba.

Aldous ('30) applying clipping treatments at two-week intervals in Kansas, found that the density of the vegetation decreased about 60 per cent in three seasons. Clipping at three-week intervals resulted in only a I 3 per cent reduction. 
Numerous other researches bear out the conclusions of these investigators. Ellett and Carrier ('I5), Stapledon ('24), Stapledon and Beddows ('26), Sturkie ('30), and Hanson et al. ('3I) are all in agreement that the total yield of forage is reduced by frequent removal of tops.

Much less work has been done to show the deleterious effects of clipping on root development. This has probably been due to the difficulty of observing closely the parts below ground.

Fitts ('25), working with fine turf grasses, found that the length of the roots increased in relative proportion to the height to which the tops had grown.

Stapledon and Beddows ('26) showed that the repeated cutting of orchard grass, Dactylis glomerata, during the growing season not only decreased the amount of hay and aftermath crop but it also reduced the root systems of the plants and retarded their growth early the following spring.

Sampson and Malmsten ('26) state that any cropping which results in the reduction of the aerial growth of grasses is reflected in the root development and in the quantity of food stored in the underground parts.

Graber et al. ('27) found that frequent and immature cutting of bluegrass reduced the amount of rhizome and root growth and increased the prevalence of weeds when compared with similar bluegrass cut at maturity.

Pierre and Bertram ('29) studied the storage of organic foods as they affect the tops and roots of kudzu, a leguminous vine. They found that the roots of plants cut six times per season decreased in weight during a period of two years, while those from plants receiving four cuttings increased about I50 per cent. The reserves of starch and nitrogen were less than one-half as great in the roots of plants receiving six cuttings as in those receiving four. Similar studies on organic food reserves have been made by Graber et al. on alfalfa ('27).

It has been shown by Parker and Sampson ('3I) that a single harvesting of the tops of Stipa pulchra and Bromus hordeaccous resulted temporarily in the cessation of root growth. Robertson ('32) found that the rate of growth of the roots of Bromus inermis diminished gradually as a result of clipping. Growth then ceased for 12 days before the roots started to die back from the tips.

Harrison ('3I) clipped grasses at different heights and concluded that the amount of roots increased with the height to which the grasses were clipped.

Robertson (' 32 ) observed that in general root penetration of seedling grasses was retarded from 35 to 62 per cent as a result of frequent clipping, and that the dry weight of the roots was reduced from 66 to 98 per cent.

Investigators are in agreement that the more frequent and drastic the cutting treatment the less is the yield of tops, rhizomes, and roots ( $c f$. ., Nelson, '25; Albert, '27; and others). An exceptional finding is that of Laird ('30) who worked in the sandy soils of Florida. He states that "the largest and deepest root system of sod-forming grasses is not necessarily associated with 
the best and most vigorous top growth. . . . mowing of centipede and Bermuda grasses increased the root growth. . . ."

\section{METHODS}

Representative bunches or clumps of several species of native grasses were selected in duplicate and removed from the unbroken prairie sod. This was done between June 28 and July 24. The species included were big bluestem, Andropogon furcatus, tall panic grass, Panicum virgatum, little bluestem, A. scoparius, slender grama, Boutelona curtipendula, and a prairie drop-seed, Sporobolus heterolepis. The first two were taken in duplicate sets and will be designated as series I and 2 . The prairie from which the preceding dominant grasses were taken has never been disturbed except by mowing. In addition, Kentucky bluegrass, Poa pratensis, blue grama grass, Boutcloua gracilis, buffalo grass, Bulbilis dactyloides, and western wheat grass, Agropyron smithii, were secured from a native pasture. Here the usual tall-grass prairie species had practically disappeared before these invaders. The pasture had not been grazed, however, since the previous summer and the grasses were all in excellent condition.

The sods of Andropogon furcatus were cut so that they each had a surface area of 25 square inches and a depth of 4 inches. Those of the other species had a similar surface area but a depth of 5 inches. Since all of these species renew activity about April I5, except Poa pratensis and Agropyron smithii which break their winter dormancy nearly a month earlier, they had already made a good growth. The height of the foliage at the time each species was transplanted and the height to which it was clipped are shown in table I.

TABLE I. Condition of the grasses at the time of transplanting. The figure in parentheses indicates the series.

\begin{tabular}{|c|c|c|c|}
\hline Species & $\begin{array}{c}\text { Date of } \\
\text { transplanting }\end{array}$ & $\begin{array}{l}\text { Height } \\
\text { tops, in. }\end{array}$ & $\begin{array}{c}\text { Height } \\
\text { clipped, in. }\end{array}$ \\
\hline Andropogon furcatus (I) & June 28 & I4 & I. 5 \\
\hline Andropogon furcatus (2) & June 28 & 20 & $\mathrm{I} .5$ \\
\hline Bulbilis dactyloides & June 28 & 6 & 0.5 \\
\hline Panicum virgatum (I) & June 28 & I5 & 1.5 \\
\hline Poa pratensis & July ro & 4 & 0.5 \\
\hline Sporobolus heterolepis & July Io & I4 & I.O \\
\hline Agropyron smithii & July Io & I6 & I.O \\
\hline Bouteloua gracilis & July I I & 8 & 0.5 \\
\hline Andropogon scoparius & July I I & Io & I.O \\
\hline Panicum virgatum (2) & $\int u l y 24$ & 34 & I.5 \\
\hline Bouteloua curtipendula & July 24 & I4 & I.O \\
\hline
\end{tabular}

The sods were transplanted into galvanized iron containers which were filled with a rich loam soil mixed with one-fifth of its volume of sand. The containers had a cross-sectional area of one square foot and varied from 2 to 2.5 feet in depth. Each sod was placed with its surface 0.5 inch below the top of the container, thus permitting watering without run-off, and the soil 
was firmly compacted about it. An opening made in the side near the bottom of each container insured proper drainage and aeration. The containers were placed in a trench 14 inches wide which was excavated in a bluegrass lawn and soil was packed around them. The trench was just deep enough so that the level of the tops of the containers was 2 inches above the general soil surface. Thus, surface water following heavy showers was prevented from running into them and a drain made in the trench prevented any accumulation of water. Thus the grasses were grown with the same variations in sunshine and temperature that they would have had in the prairie.

The soil was kept at an approximate optimum water-content for growth by frequent watering, the sods that were producing an abundance of foliage requiring water in larger amounts than the clipped ones, as was shown by soil sampling.

After the plants had become well established, one lot of each species was clipped every I4 days. The foliage produced at each clipping was placed in a drying oven at a temperature of $85^{\circ} \mathrm{C}$. for 48 hours and the dry weight determined.

The grasses were permitted to grow until October 5 to Io, when the containers were removed from the trench and placed in a large trough. They were cut open on one side and a gentle stream of water was used to wash away the soil. Such care was taken that the roots were secured almost if not quite in their entirety. The muddy water drained through a screen of fine mesh which was used to catch any broken fragments, but in any case there were but very few small pieces found. The process of washing away the soil required much care, and a whole day to lay bare the root system of a single species.

The tops were removed and their dry weight determined. The flower stalks and foliage of the unclipped grasses were, with a single exception, obtained separately. The roots were also cut away from the base of the original block of soil. The volume of the roots was obtained after all surface water had been removed by pressing the roots repeatedly for a few minutes between blotting papers.

A simple but accurate apjaratus was devised for determining the volume. A glass jar Io inches high and 3 inches in diameter had attached to it a small glass (-tul)e which served as a siphon. The jar was filled with water which was then allowed to run out to the level of the short end of the tube outside the jar. When the roots were then submerged the overflow water was caught directly in a small graduate. In measuring the volume of small root masses, the roots were placed in a 25 -cc. graduate and water was allowed to drop slowly from a burette until it reached a certain mark above the level of the roots. Care was taken to exclucle bubbles of air. The volume of roots was the difference between the number of cubic centimeters of water added and the total volume of water plus the submerged roots in the graduate.

Parts of typical roots of both the clipped and unclipped Panicum virgatum 
and Poa pratensis were selected for study. They were the portions of the roots between the fifth and tenth centimeters from the tip. These were killed in formalin-acetic-alcohol and embedded in paraffin. Slides were prepared from this material.

\section{Relative Development of Tops and Roots}

Growth of tops began almost immediately after the sods were transplanted, except in Agropyron smithii which was more mature. Here there was a delay of two weeks. Measurements made on alternate days (June 30-July I6) showed that the rate of growth, while varying considerably for the different species, was remarkably uniform within the species. The average daily rate of elongation during the first 16 days, for example, varied from $1.7 \mathrm{~cm}$. for Panicum virgatum to $2.3 \mathrm{~cm}$. for Andropogon furcatus.

Big Bluestem. The unclipped Andropogon furcatus made a luxuriant growth throughout the period of the experiment. Flower stalks began to appear on August I9 and when the grass was harvested on October 5, 45 had developed. They had an average height of 69 inches. Large, well developed fruits were produced in abundance. At this time the grass was taking on the reddish autumnal color similar to that in the prairie. The dry matter produced weighed 216.34 grams.
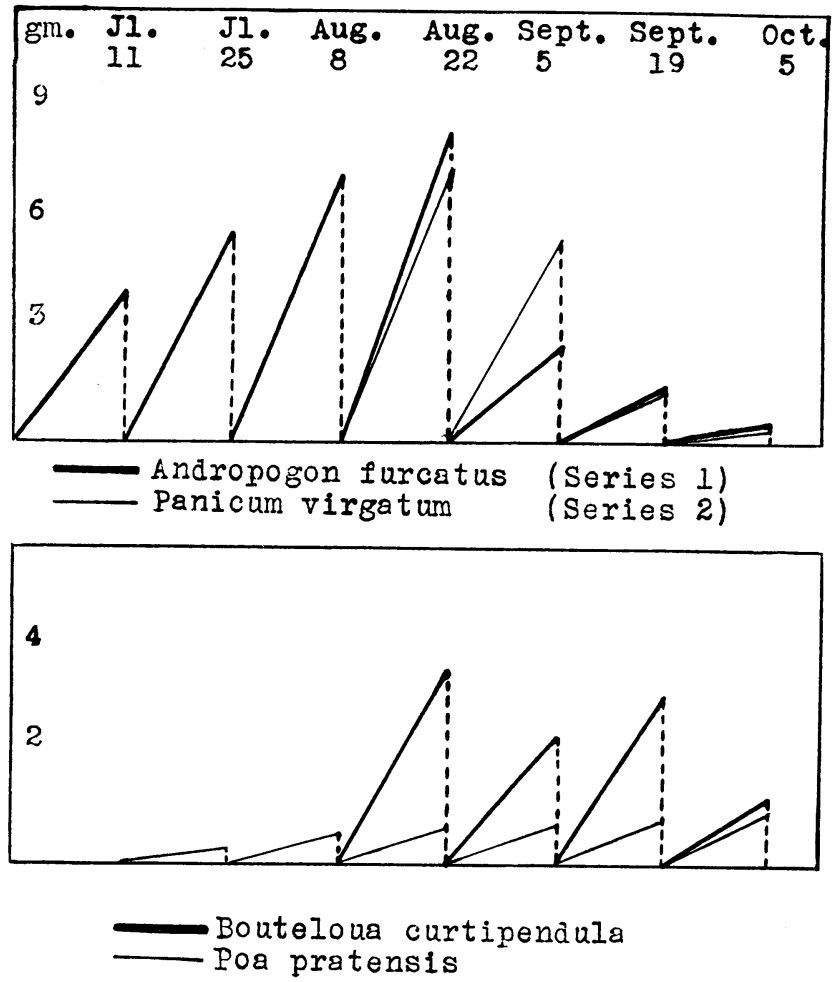

FIG. I. Amount of dry matter produced by the several grasses at each clipping. 
The amount of growth of the clipped grass increased gradually for the first four clippings. After the fourth clipping, however, both rate of growth and amount of dry matter decreased considerably (fig. I). The stand of grass was thinner after the fourth clipping since some stems did not recover and others made a growth of only i to 3 inches. Other stems grew well even after the fifth and sixth clippings, but the growth was not as great as that following the earlier ones. The total amount of dry matter produced by the clipped sod was 31.32 grams, which was only 14.5 per cent as much as that of the control.

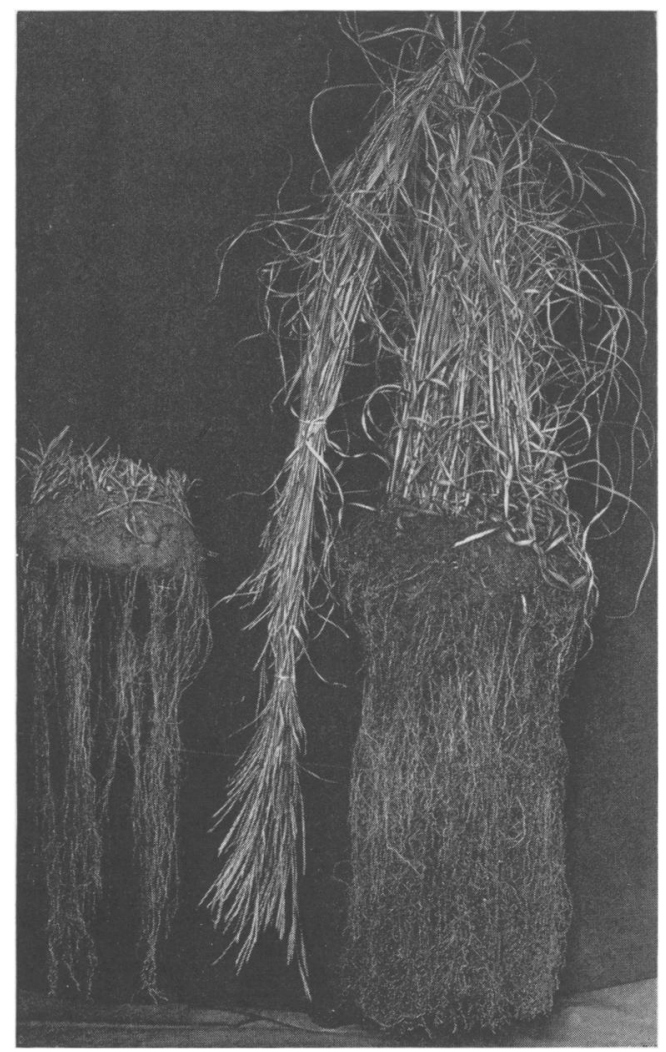

Fig. 2. Andropogon furcatus about 3 months after transplanting. Plants on the left have been repeatedly clipped.

The roots of the control formed a dense mat throughout the whole volume of soil. Those of the clipped sod were not nearly so abundant (fig. 2). Practically all of those of the control and about 30 per cent of the others extended to the bottom of the container, which was 2 feet deep. While the photograph shows the length and width of the mass of roots, it does not show the thickness of the mat, which was more than an inch when the roots were 


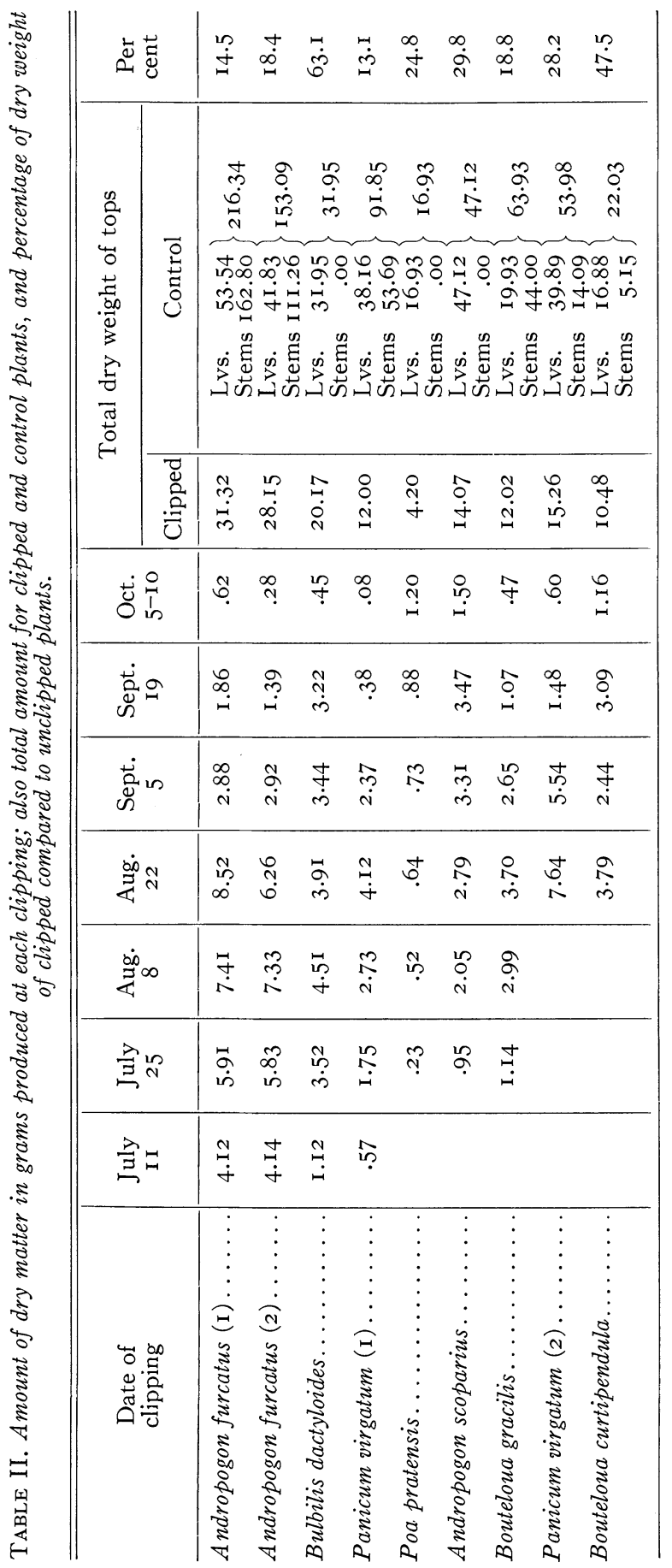


closely compacted. The volumes of the roots of the control and clipped plants were I66 and $9.2 \mathrm{cc}$. respectively, and the dry matter 4I.I 5 and 2.22 grams (tables II and III). Thus the volume of the roots of the clipped plants was only 5.5 per cent of that of the controls and the amount of dry matter produced was only 5.3 per cent as great.

TABLE III. Dry zeight and volume of roots of control and clipped plants and the per cent of dry weight and volume of the clipped compared to the control plants.

\begin{tabular}{|c|c|c|c|c|c|c|}
\hline \multirow[b]{2}{*}{ Species } & \multicolumn{3}{|c|}{ Dry weight of roots } & \multicolumn{3}{|c|}{ Volume of roots } \\
\hline & $\begin{array}{l}\text { Clipped } \\
\text { grams }\end{array}$ & $\begin{array}{l}\text { Control } \\
\text { grams }\end{array}$ & Per cent & $\begin{array}{l}\text { Clipped } \\
\text { cc. }\end{array}$ & $\begin{array}{l}\text { Control } \\
\text { cc. }\end{array}$ & Per cent \\
\hline Andropogon furcatus (I) & 2.22 & $4 \mathrm{I} . \mathrm{I} 5$ & 5.3 & 9.2 & I66.0 & 5.5 \\
\hline Andropogon furcatus (2) & I.95 & 50.00 & 3.9 & ro.I & 214.5 & 4.7 \\
\hline Bulbilis dactyloides & 3.II & II. 37 & $27 \cdot 3$ & 17.2 & 47.2 & 36.4 \\
\hline Panicum virgatum (I) & I. 55 & 58. I I & 2.6 & 9.5 & 268.0 & 3.6 \\
\hline Poa pratensis & $.4 \mathrm{I}$ & 1.99 & 20.6 & 1.9 & 10.2 & 18.6 \\
\hline Andropogon scoparius & .79 & 9.94 & 7.9 & 5.8 & 46.8 & $\mathrm{I} 2.4$ \\
\hline Bouteloua gracilis & $.4 \mathrm{I}$ & 9.75 & 4.2 & 1.9 & 54.0 & 3.5 \\
\hline Panicum virgatum (2) & .92 & 25.59 & 3.6 & 7.2 & I6r.5 & 4.4 \\
\hline Bouteloua curtipendula & I.46 & 9.32 & 15.6 & 5.0 & 30.0 & I6.6 \\
\hline
\end{tabular}

The second series of $A$. furcatus corresponded closely to the first. When harvested, there were $4 \mathrm{I}$ flower stalks with an average height of 60 inches. The total amount of dry matter was I 53.09 grams.

The amount of growth of the clipped sod increased after each of the first three clippings and then decreased rapidly. The total dry matter obtained from all the clippings was 28. I 5 grams, or I8.4 per cent as much as that of the control.

The roots of the control formed a larger mat in the bottom of the container than did those of the first series. The volume of roots of the undisturbed sod was 2 I $4.5 \mathrm{cc}$, that of the clipped sod IO.I cc. Dry weights were 50 and 1.95 grams for the unclipped and clipped plants respectively. The amount of roots produced in the second series was greater than in the first although the amount of tops was less.

Tall Panic Grass. Panicum virgatum, also transplanted on June 28, grew more slowly than that transplanted later in the season. On August I9 the flower stalks were 16 inches tall and the panicles were beginning to open. When harvested on October 8 , the foliage was 18 inches high and 40 flower stalks had developed. These averaged 30 inches in height, but some were Io inches taller. Large, well matured fruits were produced. The total amount of dry matter was 9r.85 grams.

The production of foliage by the clipped plants increased for each of the first four clippings after which there was a decrease for each of the following ones (table II). This grass seemed to be affected more by the repeated clipping than did Andropogon. After the fifth clipping there were only a few short stems produced. The total amount of dry matter was 12 grams, or I3. I per cent as much as that of the control. 
The root system of the panic grass was composed of many coarse, glistening white roots. All of the roots of the control extended to the bottom of the container but only a few of those of the clipped grass were so deep (fig. 3).

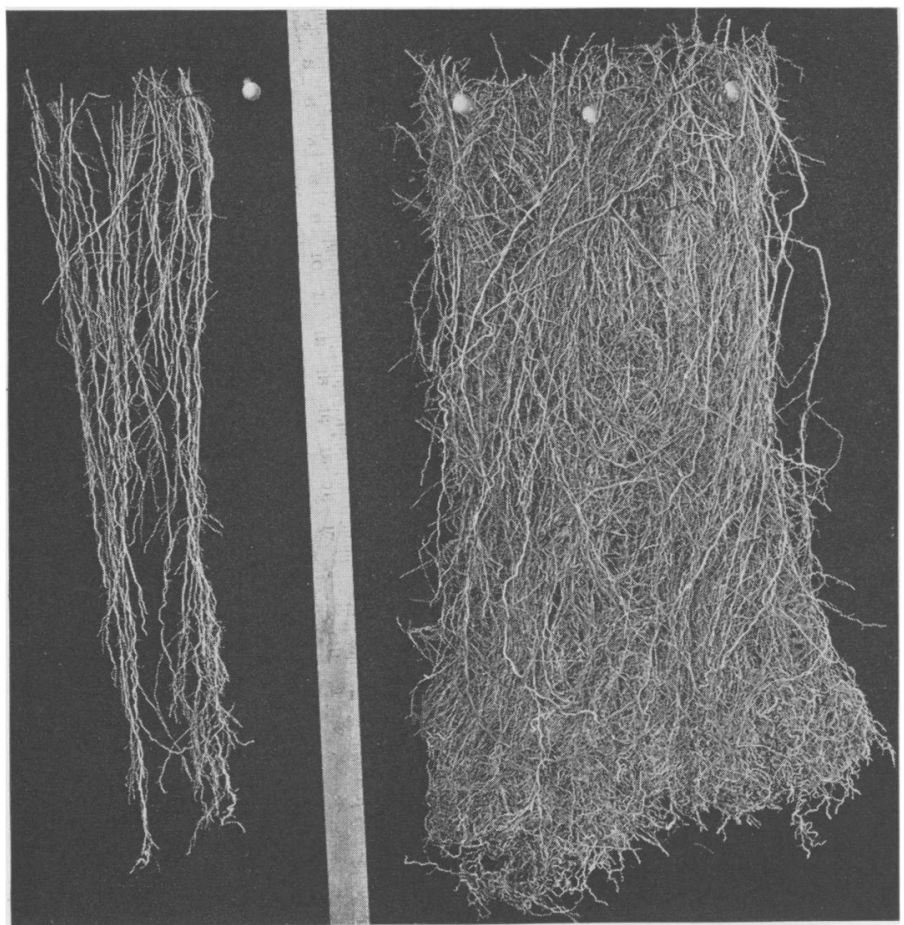

FIG. 3. Root systems of clipped (left) and unclipped Panicum virgatum nearly two feet long.

The differences in volume and dry matter produced by the two lots of sod were great. The volumes were $268.0 \mathrm{cc}$. and $9.5 \mathrm{cc}$., and the dry matter 58. I I grams and I.55 grams respectively (table III).

Panicum virgatum (series 2) was transplanted on July 24. It made a very rapid growth averaging approximately $2 \mathrm{~cm}$. increase in height per day for the first 12 days. This rapid development was probably due to the reserve food that had accumulated in the roots and rhizomes. At the time of harvest (October 8), 23 flower stalks were present. These averaged 23 inches in height, with a maximum of 32 inches. The total dry matter produced by the control grass was 53.98 grams. The amount of dry matter from the clipped sod was 7.64 grams for the first two-week period, while that of series I was only 0.57 gram. The amount of forage produced at each clipping decreased, however, after the first one (fig. I). The grass was not clipped as many times ( 4 instead of 7 ) as the first lot and the percentage of dry matter produced by the clipped as compared to the unclipped sod was correspondingly 
greater, viz., 28.2 as against I3.I. Neither the volume nor the dry weight of the roots was as great as that of the first lot, but the percentage between the clipped and unclipped plants was about the same. The roots of the clipped plants had only 4.4 per cent of the volume and 3.6 per cent of the dry weight of the controls (table III).

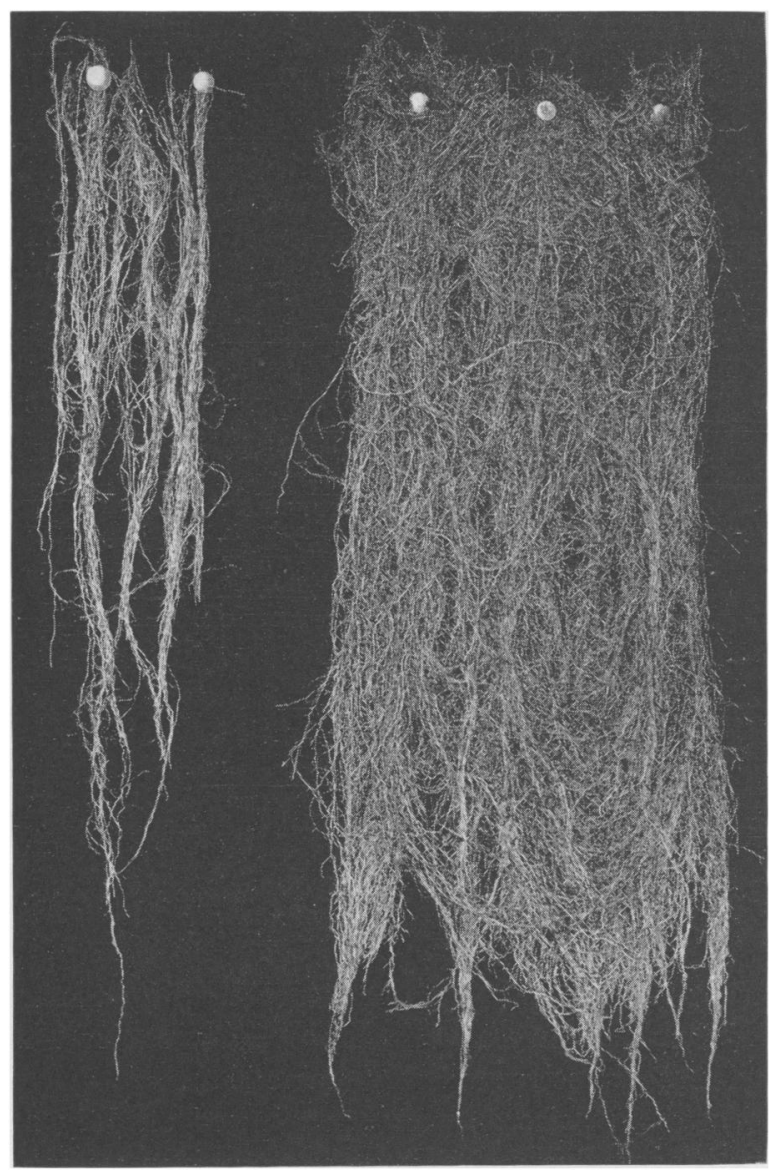

Fig. 4. Root systems of clipped (left) and unclipped Andropogon scoparius.

Little Bluestem. The control of Andropogon scoparius formed a very thick, heavy tuft of grass. A few flower stalks were developing but no fruits had been produced at the time of harvest on October Io. The dry weight of tops was 47.12 grams. The yield of tops of the treated grass increased for the first five clippings and then decreased suddenly (table II). The total dry weight of tops was 14.07 grams. An abundance of roots were produced by the control plants; they averaged $2 \mathrm{I}$ inches in length. Those of the clipped sod were few and had an average length of about I3 inches (fig. 4). The 
volume of roots was $46.8 \mathrm{cc}$. and $5.8 \mathrm{cc}$, and the dry weight 9.94 grams and 0.79 gram for the control and clipped sods respectively.

Slender Grama Grass. Bouteloua curtipendula was another species transplanted late in the season. It made a very rapid growth. When it was harvested, the 26 flower stalks averaged $2 \mathrm{I}$ inches in height (fig. 5). The fruits

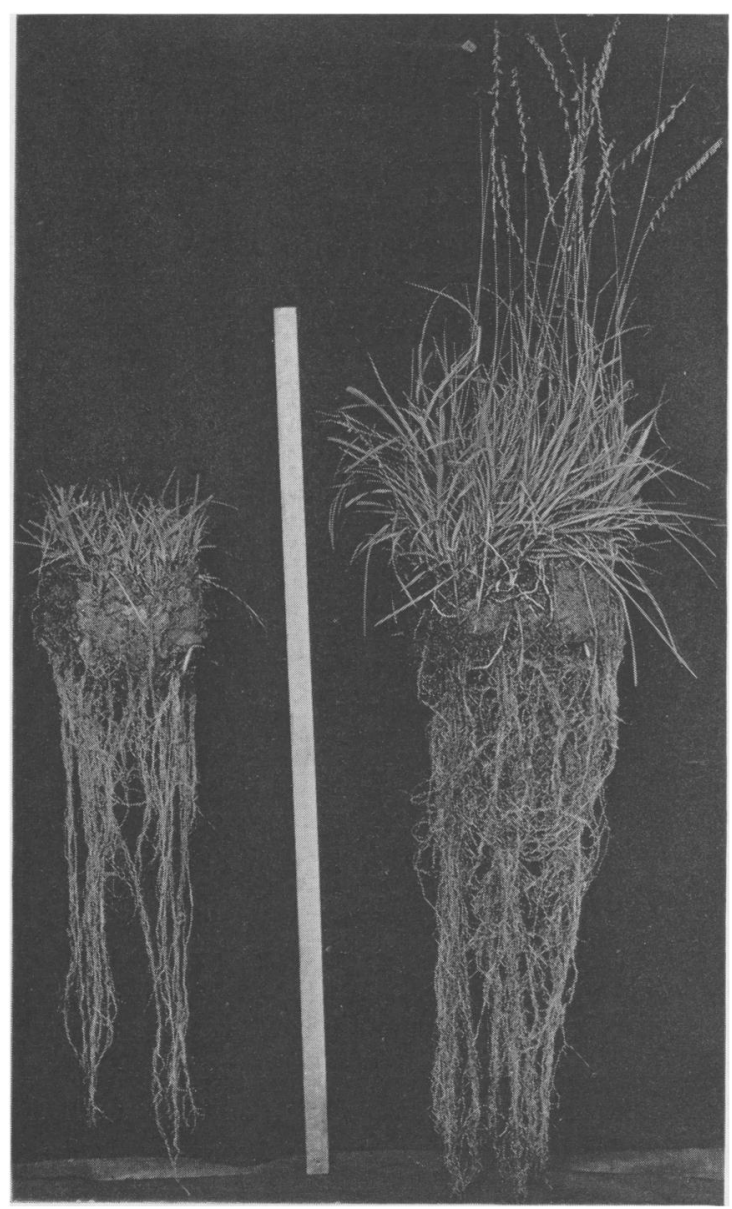

FIG. 5. Sods of Bonteloua curtipendula at the end of the experiment. The meter stick indicates the relative length of roots and tops. Unclipped sod at right.

were large and well developed but were not yet mature. The total amount of dry matter of the unclipped grass was 22.03 grams (table II). The sod from which the grass was cut every two weeks did not have its growth retarded as much as did the preceding grasses. As with Panicum virgatum (series 2), the yield was greatest at the first clipping. At the second clipping it decreased, but again increased at the third cutting (fig. I). The dry matter weighed I0.48 grams which was 47.5 per cent as great as that of the control. 
The difference in amount of roots produced by the unclipped and clipped sods was not so great as for the preceding species (table III). Most of the roots of the control grass, however, extended to the bottom of the container, but only two of those of the clipped sod penetrated so deeply.

Bluegrass. Poa pratensis makes its greatest growth in the prairie during the spring and early summer. In this experiment it developed poorly throughout the hottest part of the year. The flower stalks that were produced were few and short. The total amount of dry matter of the control was I6.93 grams while that of the clipped plant was only about one-fourth as great. There was a gradual increase in amount, however, after each of the six clippings, as shown in figure I. The percentage of dry matter produced by the clipped plants as compared to the control (24.8) was not greatly different from that of several other species. The volume of roots was 18.6 per cent and their dry weight 20.6 per cent as great as those of the control sod.

Blue Grama Grass. Bouteloua gracilis made a very fine growth which, because of a more constant water supply, was even somewhat better than that in the prairie. Very numerous flower stalks were produced which had an average height of 28 inches and yielded an abundant crop of seed (fig. 6). The total yield of tops was 63.93 grams. The amount of grass produced increased after each of the first three cuttings and then decreased after each of the three following (table II). After the clipping on August 22, flower stalks 6 inches long and flowers were produced by September I. After another clipping on September 5 , flowers were developed on stalks 3 inches long by September I2. The total amount of dry matter was 12.02 grams, which was I8.8 per cent as much as the control.

The roots of the clipped grass made a very poor growth. The average length below the sod was 9 inches, but below the unclipped sod 23 inches. The volume of the roots of the clipped plants was only 3.5 per cent as great as that of the unclipped ones, and the dry weight was 4.2 per cent as great.

Buffalo Grass. Bulbilis dactyloides differs from the other grasses in that it produces stolons. These were near the soil surface and were not removed from either the clipped or control sods until the time of the fifth clipping. There was a marked increase in dry weight of tops until the third clipping after which there was a slight but consistent decrease. The total dry matter, exclusive of the stolons, was 3I.95 grams for the control and 20.I7 grams for the clipped plants. The weight of stolons from the two sods differed by only 0.4 I gram, those from the clipped plants ( 56.24 grams) being slightly lighter.

The percentage differences in volume and dry matter of roots were not so great in this grass as in the preceding since the stolons with their numerous short leaves were not removed from the clipped sod until late in the season (table III). The volume and dry weight of the clipped plants were 36.4 and 27.3 per cent respectively of the controls.

Sporobolus heterolepis and Agropyron smithii were not harvested. Observations were made, however, which showed that the controls had the same 
abundant foliage and comparatively large amount of roots as did the other control grasses, while the roots of the clipped plants were sparse.

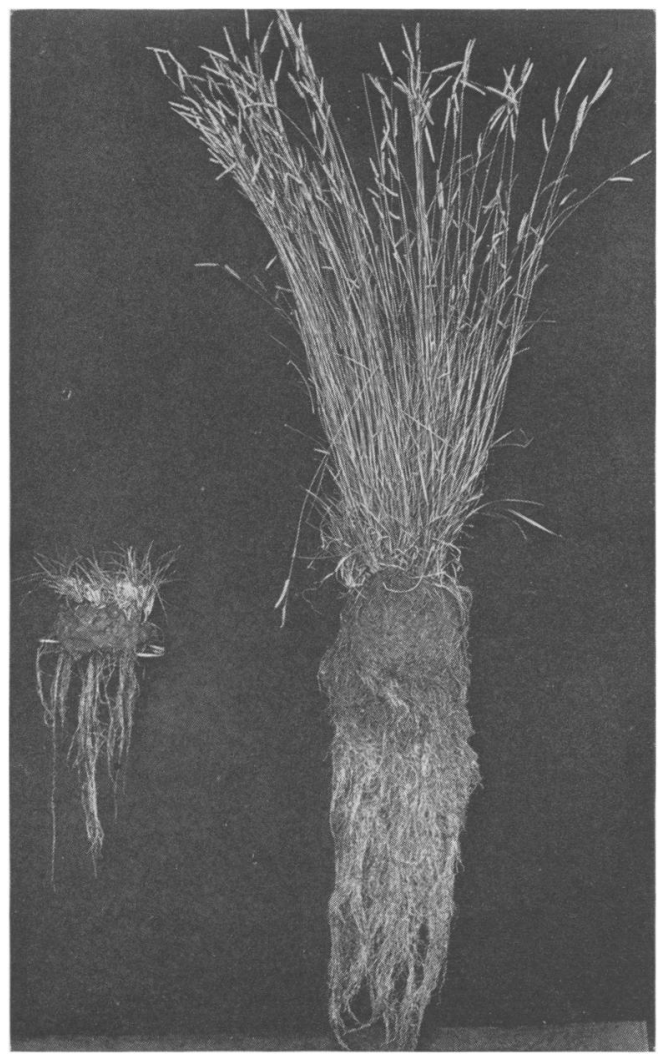

FIG. 6. Roots and tops of Bouteloua gracilis on October 9 which was 2 I days after the fifth clipping.

\section{Ejfect of Clipping on the Size and Structure of Roots}

An effect of frequent removal of the aerial parts is well shown in the relative size of the roots. The average diameter of the roots of Panicum virgatum was 1.5 and $.96 \mathrm{~mm}$. for the control and clipped sods respectively. In figure 7 the roots of the unclipped plants measured $1.6 \mathrm{~mm}$., the clipped $.96 \mathrm{~mm}$. The width of the stele was slightly greater than that of the cortex. The average diameter of the stele was about $.52 \mathrm{~mm}$. for the control plants and $.36 \mathrm{~mm}$. for the clipped ones. The root had a pith which was surrounded by large metaxylem strands. The number of strands varied for different roots. Those from the unclipped sod ranged from 7 to II ; 8, 9, and Io occurring most often. These averaged $.062 \mathrm{~mm}$. in diameter. The number of strands in roots from the clipped sod ranged from 5 to 8, 6 and 7 occurring 
most often. They were $.05 \mathrm{~mm}$. in average diameter. The number of protoxylem groups varied greatly. In the panic grass they were 4.5 to 5.5 times as numerous as the metaxylem strands. The control had 48 protoxylem points; in most cases they were composed of one strand (fig. 7). The strands averaged $.02 \mathrm{I} \mathrm{mm}$. in diameter. In the treated plants there were only 32 protoxylem points, the strands of which averaged .oI $5 \mathrm{~mm}$. in diameter. The
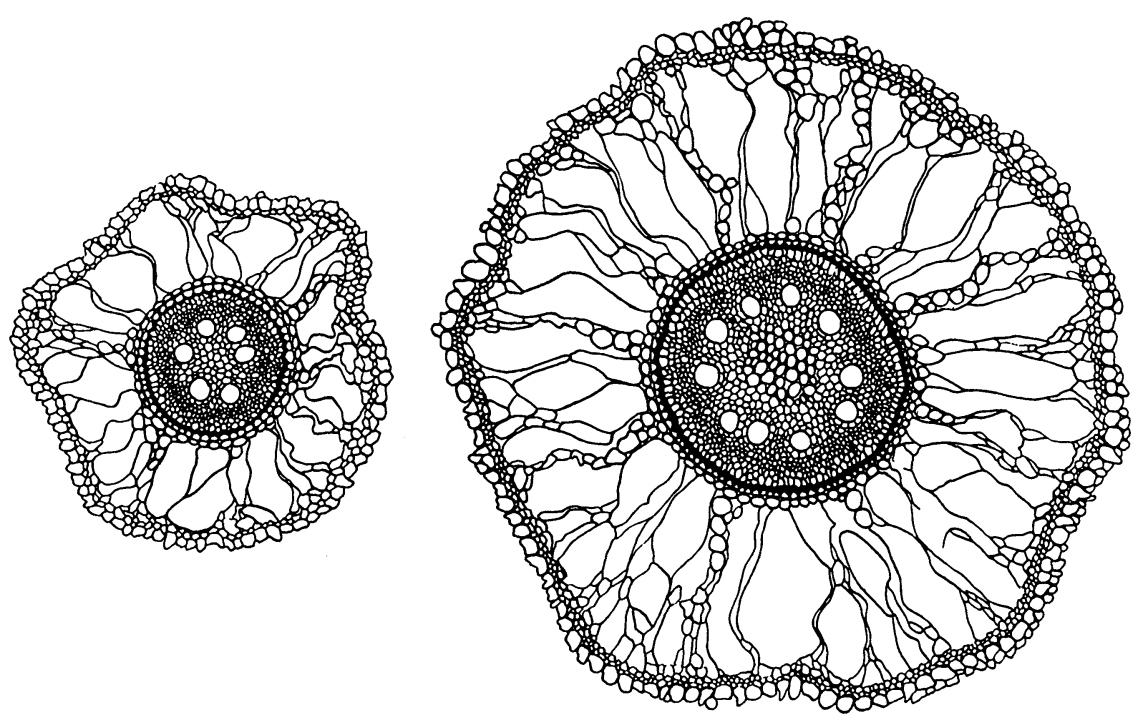

FIG. 7. Cross-sections of roots from clipped (left) and unclipped plants of Panicum virgatum drawn to same scale.
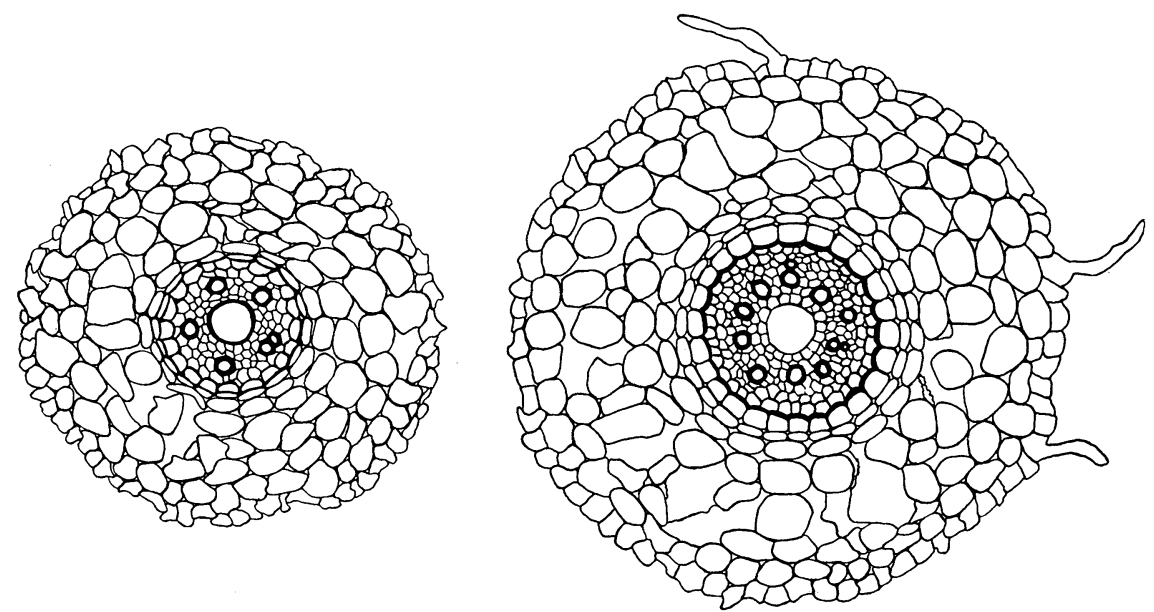

FIG. 8. Cross-sections of roots from clipped (left) and unclipped plants of Poa pratensis drawn to same scale. 
inner tangential walls of the endodermal cells were conspicuously thickened. As the root became older the cortex began to disintegrate.

Very similar results were found for Poa pratensis. The differences, however, were more constant. The average diameter of the roots of the untreated grass was $.38 \mathrm{~mm}$., that of the treated one $.29 \mathrm{~mm}$. (fig. 8). Each root was characterized by a large central metaxylem vessel which had a lignified wall. The average diameter of the central vessel for the roots of the control grass was $.036 \mathrm{~mm}$., that of the clipped one .03. The number of protoxylem elements of the polyarch system varied from 8 to II for the controls, and from 4 to 6 for the roots of the clipped grass. The diameters of the protoxylem strands of the untreated and treated plants were very similar. The average diameter of the controls was .01 $2 \mathrm{~mm}$., that of the clipped plants .oI I mm. The inner tangential wall of the endodermis was heavily thickened in the unclipped plants but less so where the tops had been repeatedly removed.

\section{Resistance to Freezing}

During the process of recovering the root systems from the soil in which they had grown, differences in the sods were observed. The control plants had apparently not only retained the network of living rhizomes but also had extended their area somewhat by the production of new ones. The clipped plants, on the contrary, had produced few or no new underground stems, and many of the old ones had died. Thus in the process of washing it was difficult to retain all of the original soil about the clipped plants. This accounts for the slightly smaller size of the blocks of sod, as shown in figures 2-6.

In order to determine the relation between the repeated removal of the tops and resistance to winterkilling, several of the sods were saved for further study. These included Andropogon furcatus, A. scoparius, Panicum virgatum (series 2), and Bulbilis dactyloides. They were placed in a box with moist soil packed firmly about them, covered with burlap, and transported to a dark room kept at a temperature of $5^{\circ} \mathrm{C}$. A week later (October I9) duplicate sods of Andropogon scoparius and Panicum virgatum were obtained from the prairie and similarly treated. On November 2, all were placed in a refrigerator maintained at a temperature of $-\mathrm{I} 2^{\circ}$ to $-\mathrm{I} 5^{\circ} \mathrm{C}$. After freezing for one week they were kept at $5^{\circ} \mathrm{C}$. for four days and then again frozen for a period of five days. After thawing for three days at $5^{\circ} \mathrm{C}$. their temperature was gradually raised until on November 20 it reached that of the greenhouse.

Containers of the sizes already described were filled with screened loess soil of good water-content. The sods were placed in the several containers and the soil packed firmly about them. Water was added regularly as required to maintain the original weight of the container and contents. Greenhouse light was supplemented on cloudy days and between 5.30 and 8.00 P.M. each day by two I 50 watt electric lights mounted in 15 -inch, white, enameled 
reflectors suspended three feet above the tops of the containers. Care was taken that each pair of sods was equally illuminated. On December I9, Poa pratensis and Stipa spartea were obtained from the prairie, where the soil had been frozen and thawed, and added to the group. They and the preceding group of untreated plants served as controls for the species employed during the summer.

The sod of Andropogon scoparius that had not been clipped until the end of the summer, renewed growth Io days after it was reset; the clipped one Io days later. At the end of 24 days, the former had developed a thick stand of grass over 3 inches high, but the weakened sod had produced only five shoots. The control plants made a good growth and were 4.5 inches tall 5 weeks after transplanting. No further growth was made by the weakened plants, two of which were dying. Neither sod had extended roots into the new soil.

The control sod of Bulbilis dactyloides produced new shoots in about Io days. At the end of five weeks a good sod 3-5 inches tall had developed but no roots extended into the soil below the sod. The grass that had been regularly clipped had been killed by freezing.

The control plants of Andropogon furcatus put forth many new shoots after a period of 20 days; the treated plants but two and only after 35 days. By January 3I, 70 days after transplanting, the 88 stems of the control had reached a height of $5^{-26}$ inches. Growth of the clipped grass was very slow and irregular. Of the 14 stems produced, 3 were dying, and the others, which were undernourished, averaged only 4 inches in height. The control had produced a good growth of roots ( $4.96 \mathrm{~g}$. dry weight), many of which were beginning to run along the bottom of the container at a depth of 2.5 feet. On the weakened plants there was a single root, about 2 inches long, extending below the sod.

Both sods of Panicum virgatum, used the previous summer, renewed growth 24 days after transplanting. At first no differences were noticeable between the two, but after a week the repeatedly clipped plants grew much more slowly. On January I 8 the control grass had 64 vigorous stalks with an average height of ro inches. The other lot had lost its deep green color, and some of the stems were dying. The 16 living shoots had a height less than one-third that of the control. These were clipped at this time. When the plants were examined two weeks later, only two stalks had made any perceptible growth, nor had any roots extended beyond the depth of the sod. The control plants, which were a foot high and thriving had developed Io new roots, the longest being nearly 2 feet. Many new rhizomes also were starting.

Summarizing, one of the clipped sods failed to grow; two were delayed Io to 15 days in renewing growth; and in all cases the grasses that had been repeatedly clipped produced only a very few weak shoots, some of which died. Two species had produced no roots five weeks after transplanting; 
the controls of the other two had good absorbing organs but the treated plants had none.

The behavior of the sods of Andropogon scoparius and Panicum virgatum secured early in the fall and artificially frozen is of interest. They renewed growth in I4 and 25 days respectively. Both developed a fairly thick growth of shoots. After two fortnightly clippings many of the shoots failed to recover and marked deterioration of tops was evident. The dry weight of tops decreased rapidly; in Panicum, for example, it was $1.28,0.78$, and $0.37 \mathrm{~g}$. respectively, for the several clippings. The unclipped plants had produced numerous flower stalks and a dry weight more than 4.5 times that of the several clippings. They had a great mass of roots that extended nearly 2.5 feet deep. The unclipped Andropogon had a good development of roots with an average depth of $\mathrm{I} 3$ inches; the clipped plants had produced none. Panicum, excavated 5 weeks after the third clipping and when the tops showed considerable recovery, had 8 roots 2 to I I inches long.

Thus renewal of growth of these new sods was similar in time to that of the previous controls. The absence of roots in Andropogon was also similar. Root development, although poor on the clipped plants, was in contrast to their lack of growth on the Panicum weakened by clipping the preceding summer.

The two lots of Poa pratensis and Stipa spartea, both species that grow early in spring, resumed growth almost immediately, when transferred from the prairie to the greenhouse in December. Both also recovered rapidly from each of three fortnightly clippings although the yield gradually decreased. The one clipping of the control Panicum, for example, was 77 per cent greater than that of the several clippings. When examined after eight weeks of growth it was found that the clipped plants had developed only a few, poorly branched roots although those of the controls were quite extensive. The control and clipped plants of Poa weighed 0.04 and $0.64 \mathrm{~g}$. respectively and those of Panicum O.I 5 and $1.67 \mathrm{~g}$. Thus the plants, although handicapped by clipping, were sufficiently vigorous to produce new roots and repeatedly regenerate the tops.

\section{Discussion}

The grasses used in these experiments are all important grazing species, Andropogon furcatus and $A$. scoparius alone constituting fully 70 per cent of the tall grass prairie (Weaver and Fitzpatrick, '32).

The regeneration of tops immediately after the original cutting (except for a delay in Agropyron) is in accord with their behavior in the prairie, two and, on low ground, sometimes three crops of prairie hay being harvested. The regeneration of tops immediately after each cutting afforded some new photosynthetic area very soon after the disturbance. Nearly all of the species commonly produce flower stalks in late autumn when mowed not later than the middle of July. Unless the herbage is removed by mowing or grazing, 
none save $P$ oa produces much foliage after midsummer, although flower stalks may develop in abundance.

That the removal of the herbage at any time prior to the maturity of the plant was followed by more or less vigorous growth is in accord with grazing experience. Similar results were found by Parker and Sampson ('3I) in their experiments with species of Stipa and Bromus.

The sods were transplanted at a time (June 28) when the growing tops had probably used considerable amounts of the root reserves, or at least before much storage for the current year had taken place. The more rapid growth of Panicum virgatum (series 2) and the other species transplanted later in the season (July 24) was probably due to a greater accumulation of reserve materials.

While some of the decrease in root production was to be expected, the amount of roots produced under clipping was surprisingly small. The extremely poor growth of the roots of the clipped Bouteloua gracilis was unexpected, since this species usually does well even under close grazing. Robertson ('32) states, however, that "In spite of clipping (of seedlings), penetration continued slowly in all species except Bouteloua, which responded by a gradual decrease in root length."

It seems probable that after transplanting, the production of new roots was delayed until the tops were well established. This was indicated by the delay in root growth of species transplanted in winter and verified by the experimental transplants the following summer. In one extreme case Andropogon scoparius produced, during a period of five weeks, an excellent growth of tops but no new roots.

Although little experimental evidence is available, it appears that the roots of grasses grow whenever the conditions are favorable and especially when the growth of shoots is not vigorous. Loeb ('24) and Janse ('25) have shown that the meristematic regions exert a profound attraction for food, water, and nutrient salts. When these regions are continually supplied with food it enables them to produce new tissues, including more meristematic tissue, which in turn further increases the demand for food. Thus there appears to exist within the block of sod competition for the accumulated food for building new roots and new shoots. These experiments indicate that for several weeks at least all or nearly all of the accumulated storage materials is used by the growing shoots and only after these are fairly well established are new roots developed. If the new shoots are again removed the process is repeated and the development of the root system is greatly retarded.

The lack of production of new rhizomes in all of the clipped sods and the death of old rootstocks, especially by winterkilling, may be directly attributed to lack of reserve food supplies and the weakened condition of the plants. McCarty ('32) has shown that in Avena fatua food accumulation is a factor of low or declining growth rate. "Inverse proportion has been shown to obtain between the food march and meristem activity, both vegetative and 
reproductive in character, and between the food march and increase in dry weight increment." Waters ('I5), Aldous ('30), and other investigators have shown that cutting frequently or cutting at immaturity depletes the reserves in the roots of herbaceous plants. The bulbs of Phleum pratense are depleted by the rapid growth of the plants. If the plants are cut at such an interval they decrease both in vigor and yield and are more susceptible to winterkilling.

Analyses of Agropyron smithii showed that low yields were associated with diminished food accumulations in the subterranean organs (McCarty, '27). The lack of growth or poor growth of tops was a direct result of food depletion. Thus low capacity for survival is a concomitant of low organic food reserves. Graber ('3I) found that unclipped potted plants of bluegrass produced abundant rhizomes while those that were clipped seven times produced none. Sturkie ('30) states that any cutting treatment of Sorghum halepense reduces the rootstock development, and the more frequently the cutting is made the greater is the reduction.

Robertson ('32) found that all but one of the six grasses with which he worked produced roots of greater diameter when the tops were uncut. Parker and Sampson (' 30 ) showed that frequent removal of the aerial growth resulted in a poorly developed root structure, in that the diameter of the whole root, the diameter of the stele, and the number of ducts were smaller than in roots of untreated specimens of the same age.

The thinning of the cover of grass by frequent removal of the tops, as in close grazing, too frequent mowing of lawns and greens, etc., includes a similar or possibly greater decrease in the abundance of roots and other underground parts. Both of these phenomena are directly related to soil erosion. In a grass plat on a hillside in Kansas, repeated clipping had reduced the density of the vegetation to about one-third normal, including about 40 per cent weeds. A rainfall of 7.5 inches in four hours eroded away approximately two inches of surface soil, but the amounts removed from any of the other fully vegetated plats was not appreciable (Aldous, '30). Forsling ('3I) states that "The increase in the density of the vegetation from I6 to 40 per cent of a complete cover and the replacement of certain plants by others with more extensive and more fibrous root systems reduced the rainfall surface run-off 64 per cent and rainfall erosion 54 per cent."

A direct relation also exists between too frequent removal of the tops, deficient root systems, and humus content of the soil. A decrease in humus results in a decreased bacterial activity since the soil population is dependent almost entirely upon the growing plant for energy material. Plants that are weakened by repeated clipping are less efficient in absorbing water and solutes. They are more subject to damage by drought, disease, and to extremes of heat or cold. They extend their area little or not at all and compete less vigorously with invaders. Invasion of weeds is an inevitable result. Not only is the annual yield of forage reduced, but the life of the plant itself is 
probably lessened. Moreover, the effects of reduced vigor persist for a long time. As pointed out by Robertson (' 32 ) the greatest reduction in yield is accompanied by the greatest reduction in root development.

The common practice of pasturing tall-grass prairie a year or more before breaking so that the sod will be less dense and more easily tilled is a practical demonstration of the harmful effects upon the underground parts resulting from the close removal of tops. Harrison ('3I) states that "Field observations as well as greenhouse studies show that Kentucky bluegrass cannot maintain itself under ordinary field conditions if it is cut shorter than threequarters of an inch more frequently than once each week." The deleterious effect of frequent cutting may, however, be offset partially by cutting the plants at a greater height above the soil. Early or frequent cutting of newly seeded lawns or newly laid sod is almost certain to result in poor establishment.

\section{SUMMARY}

This paper deals with the effects of the removal of tops on root growth in soil and on regeneration and yield of aerial parts. Blocks of well established sod of seven important native pasture grasses were transplanted into large containers, grown in the field, and clipped fortnightly.

Growth of tops, which were cut upon transplanting, was resumed immediately, as well as after each subsequent cutting from July to October. The dry weight of tops of Andropogon furcatus, A. scoparius, Panicum virgatum, Bouteloua gracilis, and Bulbilis dactyloides increased for the first three to five intervals following the initial clipping, after which it decreased rapidly. The yield of $P o a$ pratensis increased after each of the clippings. Panicum virgatum and Bouteloua curtipendula, transplanted in midsummer, decreased in yield after the first clipping. The unclipped grasses grew normally and in all cases, except one, produced flower stalks and seeds.

The total dry weight of tops from the clipped sods ranged from I3.I per cent (Panicum virgatum) to 47.5 per cent (Bouteloua curtipendula) of that of the same species unclipped after transplanting. In Bulbilis dactyloides, where the stolons were permitted to grow, it was 63. I per cent. In all cases there was a considerable decrease in the ground cover as the stand of the weakened grasses became thinner.

The clipped plants failed to produce new rhizomes and many of the old ones died.

The length of roots was greatly decreased, and the relative production of roots was more greatly reduced than that of tops. By volume, it ranged from 3.5 per cent of the controls (Boutcloua gracilis) to I 8.6 per cent (Poa pratensis), although that of Bulbilis dactyloides was 36.4 per cent. The dry weight varied from 2.6 per cent in Panicum virgatum to 20.6 in Poa pratensis. The average volume of roots of the clipped sods was I I.7 per cent of that of the controls; the average dry weight was Io. I per cent. 
The roots of the clipped grasses were smaller in diameter than were those of the controls. The diameter of those of Poa pratensis was 76 per cent as great and those of Panicum virgatum only 64 per cent.

Plants weakened by repeated clipping renewed growth slowly if at all after being frozen. No new roots were produced during the period of the experiment by those that survived.

The harmful effects of the frequent removal of the cover of grasses and the accompanying deterioration of the parts underground are discussed.

\section{Literature Cited}

Albert, W. B. 1927. Studies on the growth of alfalfa and some perennial grasses. Jour. Amer. Soc. Agron., I9: 624-654.

Aldous, A. E. 1930. Effect of different clipping treatments on the yield and vigor of prairie grass vegetation. Ecology, Ir: 752-759.

Clements, F. E., and J. E. Weaver. I924. Experimental vegetation. Carn. Inst. Wash. Publ. No. 355. 25-26, 66-70.

Crozier, A. A. 1897. Forage plants and wheat. Mich. Exp. Sta. Bull. I4I. I30I32.

Ellett, W. B., and L. Carrier. I9I5. The effect of frequent clipping on total yield and composition of grasses. Jour. Amer. Soc. Agron., 7: 85-87.

Fitts, O. B. I925. Root growth of fine grasses. Greens Section Bull. U. S. Golf A., 5: $58-62$.

Forsling, C. L. 1931. A study of the influence of herbaceous plant cover on surface run-off and soil erosion in relation to grazing on the Wasatch plateau in Utah. U. S. Dept. Agric. Tech. Bull. 220.

Graber, L. F. I93I. Food reserves in relation to other factors limiting the growth of grasses. Plant Physiology, 6: 43-7I.

- - , et al. 1927. Organic food reserves in relation to the growth of alfalfa and other perennial herbaceous plants. Wis. Agric. Exp. Sta. Research Bull. 8o.

Hanson, H. C., L. D. Love, and M. S. Morris. I93I. Effects of different systems of grazing by cattle upon a western wheat-grass type of range. Col. Exp. Sta. Bull. 377 .

Harrison, C. M. I93I. Effect of cutting and fertilizer applications on grass development. Plant Physiology, 6: 669-684.

Janse, J. M. 1925. Ernahrung, Adventivbildung und Polaritat. Flora, Ir8-II9: 257-288.

Laird, A. S. 1930. A study of the root systems of some important sod-forming grasses. Fla. Agric. Exp. Sta. Bull. $2 \mathrm{II}$.

Loeb, J. I924. Theory of regeneration based on mass action. Jour. Gen. Physiology, 6: 207-214.

McCarty, E. C. 1927. Grazing intensities and food relationships in Agropyron smithii. (Thesis.) Cited in Sampson and McCarty, '30.

- - 1932. Some relations between the carbohydrates and the growth rate in the wild oat, Avena fatua. Oc. Pap. Riverside Jr. Col., 6: I-32.

Nelson, N. T. 1925. The effects of frequent cutting on the production, root reserves, and behavior of alfalfa. Jour. Amer. Soc. Agron., I7: 100-II3.

Parker, K. W., and A. W. Sampson. I930. Influence of leafage removal on anatomical structure of roots of Stipa pulchra and Bromus hordeaceus. Plant Physiology, 5: 543-553.

- - - - 1931. Growth and yield of certain Gramineae as influenced by reduction of photosynthetic tissue. Hilgardia, 5: 36 $\mathrm{I}-38 \mathrm{r}$. 
Pierre, W. H., and F. E. Bertram. I929. Kudzu production with special reference to influence of frequency of cutting on yields and formation of root reserves. Jour. Amer. Soc. Agron., 21: I079-i Ior.

Robertson, J. H. I933. Effect of frequent clipping on the development of certain grass seedlings. Plant Physiology, 8: 425-447.

Sampson, A. W. I9I4. Natural revegetation of range lands based upon growth requirements and life history of the vegetation. Jour. Agric. Res., 3: 93-147.

- and E. C. McCarty. 1930. The carbohydrate metabolism of Stipa pulchra. Hilgardia, 5: 6I-100.

- - and H. E. Malmsten. I926. Grazing periods and forage production on the national forests. U. S. Dept. Agric. Dept. Bull. I405.

Sarvis, J. T. I923. Effects of different systems and intensities of grazing upon the native vegetation at the northern great plains field station. U. S. Dept. Agric. Dept. Bull. I I 70.

Stapledon, R. G. I924. The seasonal productivity of herbage grasses with particular reference to the influence of different systems of cutting on indigenous and non-indigenous strains respectively. Welsh Plant Breeding Sta. Bull., 3: $6 \mathrm{I}-74$.

- and A. R. Beddows. 1926. The quantitative and qualitative response of cocksfoot (Dactylis glomerata L.) to sodium nitrate and to superphosphate. Welsh Jour. Agric., 2: 103-II3.

Sturkie, D. G. 1930. The influence of various top-cutting treatments on rootstocks of Johnson grass (Sorghum halepense). Jour. Amer. Soc. Agron., 22: 82-93.

Waters, H. J. I9I5. Studies of the timothy plant, part I. The influence of maturity upon the yield, composition, digestibility, palatability, and feeding value of timothy hay. Mo. Agric. Exp. Sta. Res. Bull. I9.

Weaver, J. E., and T. J. Fitzpatrick. 1932. Ecology and relative importance of the dominants of tall-grass prairie. Bot. Gaz., 93: I13-150. 